Institute of $\mathbf{F}_{\text {ood and }} \mathbf{A}_{\text {gricultural }} \mathbf{S}_{\text {ciences }}$

\title{
Retrofitting a Traditional In-ground Sprinkler Irrigation System for Microirrigation of Landscape Plants ${ }^{1}$
}

\author{
Dorota Z. Haman, Michael D. Dukes, and Sydney G. Park-Brown ${ }^{2}$
}

\section{Introduction}

Florida's increasing population, along with recent droughts, have put water resources throughout the state under stress. In some areas, irrigation of lawns and landscapes have been restricted to once or twice a week. Microirrigation -- because of its efficient use of water -- has been exempt from such restrictions (see Figures 1-4 ). Microirrigation is also being encouraged or mandated in recently drafted landscape ordinances. For these reasons, there is increasing use of microirrigation in the landscape, both as new installations and in retrofits of older irrigation systems.

A retrofit of an irrigation system must be done very carefully in order to ensure that the entire system will function properly and will provide uniform and efficient water application. This publication provides important information and precautions that must be considered when retrofitting an existing irrigation system to microirrigation.

Most in-ground irrigation systems are divided into zones. When retrofitting a zone, it is advisable to convert the entire zone to microirrigation rather than mixing in shrub sprays or rotary sprinklers (See
Figures 5-7). Shrub sprays and rotors apply water much faster (gallons per minute) than microirrigation emitters (gallons per hour). Therefore, the time needed to apply a set amount of water can vary widely with the type of sprinkler or emitter.

If a mixed zone (that is, a zone that includes microirrigation and traditional spray heads or rotors) is the only feasible solution, it should be installed very carefully in order not to disturb the original design and to assure as high system efficiency as possible under existing conditions.

Generally, it is not recommended that the system include various heads within the same zone, since often, different emitting devices require different run times for efficient water application. For example, with proper spacing, water is applied much faster with spray heads (Figure 5) than with rotary sprinklers (Figure 6) or impact sprinklers (Figure 7). As a result, spray zones are run for much shorter times than sprinkler zones to apply the same amount of water.

Switching a zone from overhead to microirrigation may result in a lower flow rate (less water) for that zone. A lower flow rate may create a

1. This document is ABE324, one of a series of the Agricultural and Biological Engineering Department, Florida Cooperative Extension Service, Institute of Food and Agricultural Sciences, University of Florida. First published October 2002. Please visit the EDIS Web site at http://edis.ifas.ufl.edu.

2. Dorota Z. Haman, professor; Michael D. Dukes, assistant professor; both Agricultural and Biological Engineering Department; Sydney G. Park-Brown, extension agent IV, Hillsborough County. Institute of Food and Agricultural Sciences, University of Florida, Gainesville.

The Institute of Food and Agricultural Sciences is an equal opportunity/affirmative action employer authorized to provide research, educational information and other services only to individuals and institutions that function without regard to race, color, sex, age, handicap, or national origin. For information on obtaining other extension publications, contact your county Cooperative Extension Service office. Florida Cooperative Extension Service/Institute of Food and Agricultural Sciences/University of Florida/Christine Taylor Waddill, Dean. 
problem in an irrigation system depending on the source of water. Converting an irrigation system to microirrigation requires planning based on the type of water supply. There are several possible cases:

\section{Municipally supplied water}

2. Household water with a pressure tank

3. Irrigation well without a pressure tank

4. Irrigation system inlet located before the pressure tank

\section{Municipally supplied water}

Irrigation systems operating on city water or county-supplied water are the easiest to retrofit. This is also the most economical type of retrofit, with the maximum potential water savings. The water is supllied under pressure, and there is no pump in the system. When a zone is converted to microirrigation, the flow to the zone should be the same or less than the original flow to this zone. The components' size should be sufficient for the new flow rate. The length of time the zone is run during each irrigation will depend on the the type of emitters, emitter water pattern, and spacing. This type of retrofitting allows for the most efficient water management. For example, if the zone previously had 3 overhead sprinklers rated at $3.4 \mathrm{gpm}$, the total flow to the zone was approximately $10 \mathrm{gpm}$ (or 600 gallons per hour). Since microdevices are usually rated in gallons per hour (gph), a maximum of 600 one-gallon-per-hour emitters could be used (or 300 two-gph emitters or no more than 600 feet of drip tape rated at 0.1 $\mathrm{gpm} / 100 \mathrm{ft}$ ). It is also very important to reduce the existing pressure of this zone to the pressure recommended for the selected micro-emitters. Most of them operate somewhere in the range of 8-12 psi for drippers and 10-25 for microjets and microsprinklers. An in-line pressure reducer should be added to each zone being retrofitted.

\section{Household Well with a Pressure Tank}

A household well with a pressure tank acts in a way similar to the city water supply. The water is provided "on demand" from the pressure tank if the flow is less than the design flow of the pump. If the flow is equal to pump flow, the pump operates continuously. The new flow rates to the zones should be similar or lower than previous flows to assure that the parts of the system are appropriately sized.

\section{Irrigation Well without a Pressure Tank}

An irrigation system in this case is more difficult to retrofit. A well not used as a water supply for the house may not have a pressure tank installed. These types of systems are sensitive to any change in the flow rate of any zone. Assuming that the existing high-pressure sprinkler system is well designed, each zone should have approximately the same flow rate to avoid pump cycling that may result in pump damage. In this case, it is critical to maintain the same flow into the zones after changing to microirrigation. The difference between retrofitting the previous systems and these is that the flow rate cannot be reduced.

\section{Irrigation System Inlet Located Before Pressure Tank}

In the case where the system is not "on demand", it may be modifiable to a demand system by replumbing the irrigation supply line after the pressure tank. This makes the system flexible and will provide conservation of water after the zones are modified with microirrigation. If the pressure tank can not be relocated, this situation is the same as case 3.

\section{Putting it All Together}

Let's assume that we want to replace one sprinkler head that is irrigating a flower bed with a drip line. The flow to this sprinkler is $3.4 \mathrm{gpm}$. After removing the sprinkler head, a fitting which will accommodate whatever microirrigation device you plan to use should be attached to the outlet. Microirrigation systems operate at lower pressures and often can be damaged by the pressure required for the previous sprinkler. Therefore, the new fitting should lead to an in-line pressure regulator which will reduce the water pressure to the psi recommended by the manufacturer of the device (normally in a range of 8-12 psi). Then, the drip tape or poly-tubing can be attached to the outlet of the pressure regulator. If well water is used and water quality is poor, a small 
in-line filter should be installed before the drip tape or tubing. This is usually not necessary for a municipal water supply. The length of tape or the number of emitters on the tubing should be calculated based on the flow.

It is important to make sure that a retrofit will not affect how uniformly water is applied to the landscape or dry spots will result. Decreasing the uniformity may also result in lowering the overall efficiency of the system and may make system management much more difficult.

\section{Summary}

Four general cases of irrigation system retrofits have been discussed in this publication. The goal of retrofitting is to change existing high flow-rate spray heads and/or rotors low flow microirrigation devices. "Microirrigation devices" are defined as follows by the American Society of Agricultural Engineers (ASAE) as follows (Table 1):

Table 1. Flow rate specifications for various types of microirrigation.

\begin{tabular}{|l|l||}
\hline \hline Type & $\begin{array}{l}\text { Flow rate } \\
\text { (gallons per hour, } \\
\text { gph) }\end{array}$ \\
\hline less than 60 \\
\hline Dubbler & less than 2 \\
\hline Drip tube or tape & less than 1 per ft \\
\hline $\begin{array}{l}\text { Microspray or } \\
\text { microjet }\end{array}$ & less than 45 \\
\hline \hline
\end{tabular}

If modifications are done according to the guidelines presented here, there will be a potential water savings if the system is managed properly. Table 2 summarizes some facts about reotrofit options.

\section{References}

ASAE. 2001. Design and installation of microirrigation systems. American Society of Agricultural Engineers Standards, EP405.1, St. Joseph, Michigan.

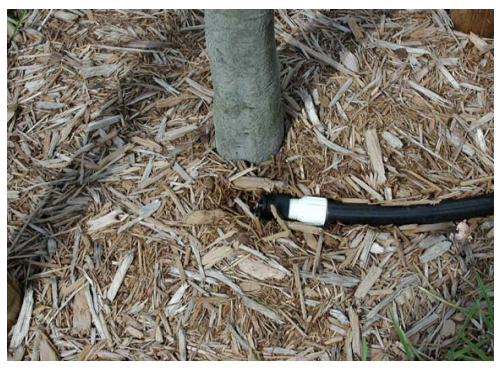

Figure 1. Types of microirrigation emitters: Bubbler.

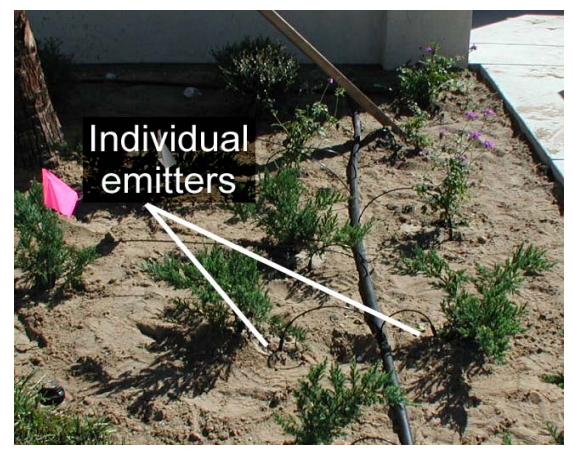

Figure 2. Types of microirrigation emitters: Drip emitters.

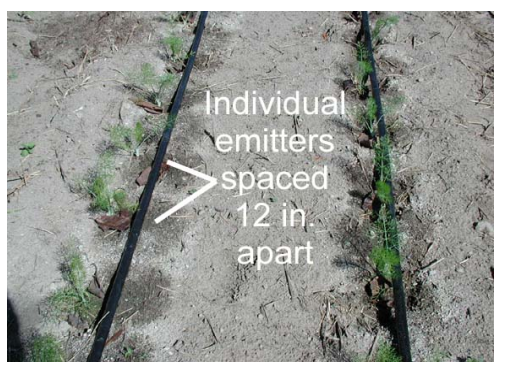

Figure 3. Types of microirrigation emitters: Drip tube or tape.

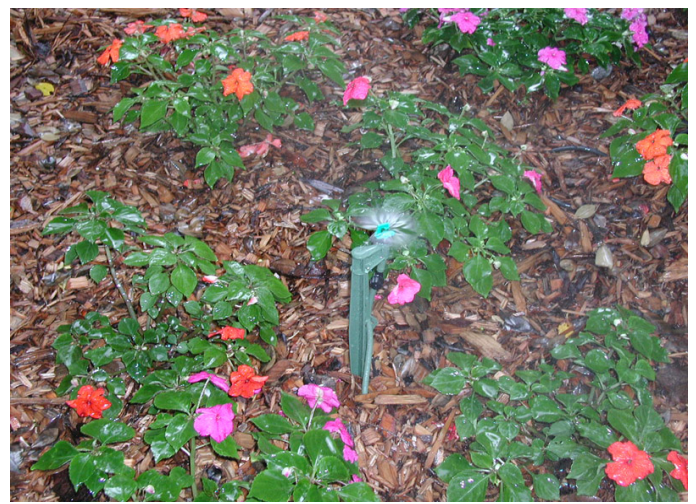

Figure 4. Types of microirrigation emitters: Microspray or microjet. 


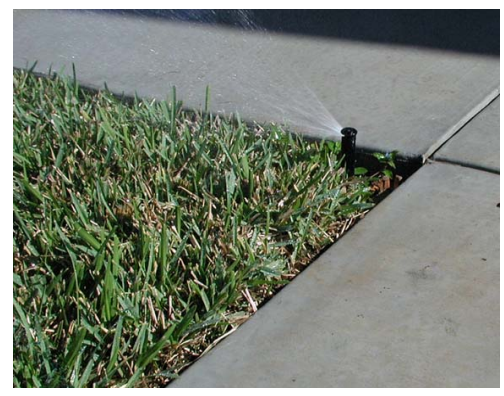

Figure 5. Type of traditional landscape and turf irrigation emission devices: Spray head.

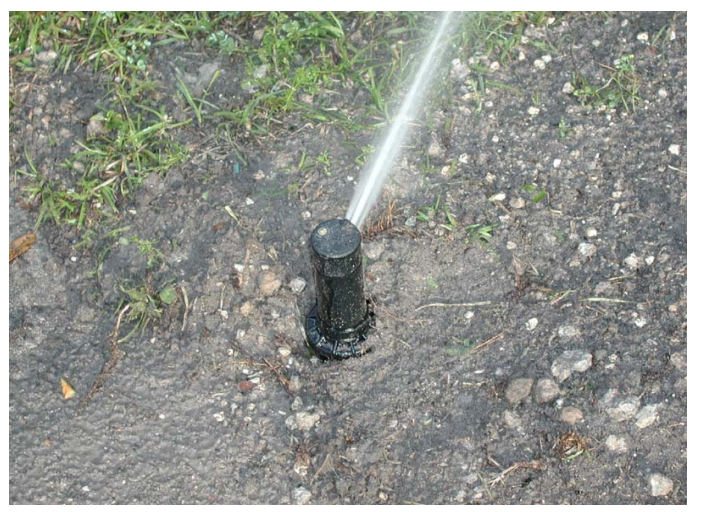

Figure 6. Type of traditional landscape and turf irrigation emission devices: Gear-driven rotor sprinkler.

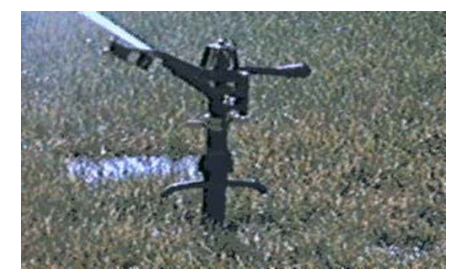

Figure 7. Type of traditional landscape and turf irrigation emission devices: Impact sprinkler. 
Retrofitting a Traditional In-ground Sprinkler Irrigation System for Microirrigation of....

Table 2. Retrofit options, difficulty level, potential water savings, and negative impact on uniformity.

\begin{tabular}{|c|c|c|c|c|c|}
\hline Case & Description & $\begin{array}{l}\text { Level of } \\
\text { retrofit }\end{array}$ & $\begin{array}{l}\text { Difficulty } \\
\text { of retrofit }\end{array}$ & $\begin{array}{l}\text { Potential } \\
\text { water } \\
\text { savings }\end{array}$ & $\begin{array}{l}\text { Potential } \\
\text { negative } \\
\text { impact on } \\
\text { uniformity }\end{array}$ \\
\hline 1 & City water & $\begin{array}{l}\text { Entire } \\
\text { zone }\end{array}$ & Low & High & High \\
\hline 2 & $\begin{array}{l}\text { Irrigation well or surface } \\
\text { water with pressure tank }\end{array}$ & $\begin{array}{l}\text { Entire } \\
\text { zone }\end{array}$ & Low & High & High \\
\hline 3 & $\begin{array}{l}\text { Irrigation well or surface } \\
\text { water without pressure } \\
\text { tank }\end{array}$ & $\begin{array}{l}\text { Entire } \\
\text { zone }\end{array}$ & High & Low & High \\
\hline 4 & $\begin{array}{l}\text { Irrigation system inlet } \\
\text { before pressure tank }\end{array}$ & $\begin{array}{l}\text { Entire } \\
\text { zone }\end{array}$ & Medium & Low & High \\
\hline 5 & City water & $\begin{array}{l}\text { Partial } \\
\text { zone }\end{array}$ & Low & High & High \\
\hline 6 & $\begin{array}{l}\text { Irrigaton well or surface } \\
\text { water with pressure tank }\end{array}$ & $\begin{array}{l}\text { Partial } \\
\text { zone }\end{array}$ & Low & High & High \\
\hline 7 & $\begin{array}{l}\text { Irrigation well or surface } \\
\text { water without pressure } \\
\text { tank }\end{array}$ & $\begin{array}{l}\text { Partial } \\
\text { zone }\end{array}$ & High & Low & High \\
\hline 8 & $\begin{array}{l}\text { Irrigation system inlet } \\
\text { before pressure tank }\end{array}$ & $\begin{array}{l}\text { Partial } \\
\text { zone }\end{array}$ & Medium & Low & High \\
\hline
\end{tabular}

